\title{
Effect of change of diet on the mineral composition of rumen fluid, on magnesium metabolism and on water balance in sheep
}

\author{
BY C. L. JOHNSON AND D. A. AUBREY JONES \\ Department of Animal Physiology and Nutrition, University of Leeds, Leeds LS2 9JT
}

(Received 29 June 1988 - Accepted 5 December 1988)

1. The effects of four diets on water intake, rumen fluid outflow-rate, rumen $\mathrm{pH}$ and mineral metabolism were studied in wether sheep. The diets were barley and hay, flaked maize and hay, dried grass and frozen grass.

2. Experimental periods were of $12 \mathrm{~d}$ duration, and plasma magnesium concentrations were lower at the end of treatment periods when the grass diets were given and were significantly different $(P<0.05)$ at 11.00 and 20.45 hours. Also, the concentration was significantly lower with the dried-grass diet than with the frozen-grass diet ( $P$ $<0.05$ ).

3. The concentration of $\mathrm{Mg}$ in rumen fluid centrifuged at $30000 \mathrm{~g}$ (ultracentrifuged) varied with the diet. Maximum concentrations $\left(t_{\max }\right)$ were reached $4 \mathrm{~h}$ later on the grass diets than on the hay and concentrate diets. In the latter case $t_{\max }$ coincided with that for calcium, potassium, chloride and ammonia. At this time sodium and phosphate were at a minimum. The concentration of $\mathrm{Mg}$ in ultracentrifuged rumen fluid was negatively correlated $(r-0.89)$ with $\mathrm{pH}$, which was significantly higher $(P<0.01)$ at all times on the grass diets. This relation was also reflected in the apparent availability of $\mathrm{Mg}$.

4. Total water intake on the frozen grass was about twice that on the barley and hay diet. The outflow rate of liquid from the rumen was higher on the frozen grass than on the other three diets.

5 . The proportion of absorbed $\mathrm{Mg}$ excreted in urine was significantly influenced by diet.

It is well known that there is a fall in the plasma magnesium concentration of cattle and sheep immediately following a change of diet from forage and concentrates to young grass. This occurs even when diets are isomagnesaemic (Care et al. 1967).

More recently, Johnson et al. (1988) have shown a fall in plasma $\mathrm{Mg}$ concentration when lactating Jersey cows were changed from a diet of hay and concentrates to one of frozen grass ( $a d$ lib.), even though the daily intake of $\mathrm{Mg}$ increased by approximately $44 \%$ on the grass diet. The concentrations of ultrafilterable $\mathrm{Mg}$ and calcium in rumen fluid varied inversely with $\mathrm{pH}$. There were also changes in water intake, rumen volume, dilution- and outflow-rates associated with the diets.

Using grass from the same harvest but conserved by ensiling, by artificially drying or by deep-freezing, Powley \& Johnson (1977) showed in ewes that the extent of the fall in plasma $\mathrm{Mg}$ concentration was influenced by the method of herbage conservation. The apparent availability of herbage $\mathrm{Mg}$ also varied with the method of conservation.

The present experiment was made to study the effect of method of conservation of grass and of diets containing cereal with different fermentation characteristics on rumen $\mathrm{pH}$, water intake, rumen volume and liquid outflow rates and on $\mathrm{Mg}$ metabolism in sheep fed on controlled amounts of food.

MATERIALS AND METHODS

Sheep

Four rumen-cannulated wether sheep ranging in weight from 47 to $64 \mathrm{~kg}$ were used, and treatments were allocated in a $4 \times 4$ Latin-square design. At $10 \mathrm{~d}$ before the experiment began the sheep were housed in metabolism crates and fed on hay and pelleted concentrates. 


\begin{abstract}
Diets
The four experimental diets were $(\mathrm{g} / \mathrm{kg}) 600$ rolled barley +400 chopped hay $(\mathrm{BH})$ (control), 600 flaked maize +400 chopped hay $(\mathrm{MH})$, dried-grass cobs (DG), frozen grass (FG). FG was primary growth from a field in which cases of clinical hypomagnesaemia had recently occurred in cattle. Immediately after harvesting the grass was stored at $-20^{\circ}$ until required for feeding.

Each sheep was fed according to its metabolic weight $(0.05 \mathrm{~kg}$ food dry matter (DM) $/ \mathrm{kg}$ live weight ${ }^{0.73}$ per $24 \mathrm{~h}$ ) and the same quantity of food DM was supplied for all diets. Food was offered twice daily at 09.00 and 21.00 hours. Refusals were removed and weighed once daily before the first feed. Distilled water was continuously available from individual troughs. On the 1 st day of a treatment period water intake was recorded at 09.00 and 21.00 hours immediately before feeding. Thereafter it was recorded once daily at 09.00 hours.
\end{abstract}

\title{
Experimental procedure
}

Each experimental period lasted $12 \mathrm{~d}$. At the end of each period the diets were abruptly changed, the new ones being given at 09.00 hours on the first day of a new treatment period.

On the last $6 \mathrm{~d}$ of each period a balance study was carried out with separate total collections of urine and faeces. Faeces were collected each day at about 08.45 hours, weighed and stored in plastic bags at $4^{\circ}$. At the end of a balance period the output from each animal was bulked, mixed thoroughly and sampled in duplicate. One sample was kept at $-20^{\circ}$. The DM content of the other sample was determined by drying in a hot-air oven at $100^{\circ}$ for $24 \mathrm{~h}$. This dried sample was then ground through a $1 \mathrm{~mm}$ sieve.

The total daily output of urine from each sheep was collected at 08.45 hours and its $\mathrm{pH}$ and volume measured. It was then stored in a polyethylene drum to which had been added $500 \mathrm{ml}$ glacial acetic acid. At the end of the balance period the urine was well mixed and sampled in duplicate. The samples were stored at $-20^{\circ}$ until analysis.

On each day of a balance period approximately $100-\mathrm{g}$ samples of each food were put in plastic bags. The samples of frozen grass were stored at $-20^{\circ}$. Representative samples of all food refusals were taken and stored in a similar manner. At the end of a balance period all food samples for each sheep were bulked, mixed thoroughly and subsampled. The duplicate samples were dried at $100^{\circ}$ in a hot-air oven for $24 \mathrm{~h}$ to determine their DM contents and then ground through a $1 \mathrm{~mm}$ sieve.

Blood samples were taken either via vacutainer tubes or indwelling jugular catheters. Two samples were taken on days 1,2 and 3 at 08.45 and 20.45 hours and one at 08.45 hours on the 4th day. On the 11 th and 12th days samples were taken at $08.45,11.00,15.00$ and 20.45 hours.

Samples of rumen fluid were taken via rumen cannulas from the upper, central, lower and lower fore-parts of the runien (Lane et al. 1968). Approximately $80 \mathrm{ml}$ fluid were taken on each occasion and were well mixed and sampled. The samples were centrifuged at 2000 $g$ for $10 \mathrm{~min}$ and then stored in stoppered plastic tubes at $-20^{\circ}$. Excess fluid was returned to the rumen.

Samples were collected on the 2 nd day at 11.00 hours and on the 11 th and 12 th days at $08.45,11.00,15.00$ and 20.45 hours (after blood sampling) and the $\mathrm{pH}$ was measured immediately. Rumen fluid volume and dilution-rate were measured on the 8 th day of each sampling period using polyethylene glycol (PEG). PEG $(25 \mathrm{~g})$ was dissolved in $200 \mathrm{ml}$ distilled water and injected throughout the rumen contents in $20-\mathrm{ml}$ portions at 14.15 hours. Samples of fluid were then withdrawn serially $1,2,3,4$ and $6 \mathrm{~h}$ after injection.

The potential difference (PD) across the rumen wall was measured on the 10 th day at 11.30 and 15.30 hours. 
Food and faeces were analysed for DM, total ash, $\mathrm{Mg}$, calcium, phosphate, sodium and potassium. Urine was analysed for $\mathrm{pH}, \mathrm{Mg}, \mathrm{Ca}$ and phosphate.

Blood samples were analysed for packed cell volume and the plasma concentrations of $\mathrm{Mg}, \mathrm{Ca}$ and phosphate. The osmotic pressure of rumen fluid was measured and samples were analysed for the concentrations of ammonia, $\mathrm{Mg}, \mathrm{Ca}$, phosphate, $\mathrm{Na}, \mathrm{K}$ and chloride.

\section{Analytical methods}

Dried samples of food and faeces were first prepared for mineral analyses by the procedure of the Ministry of Agriculture, Fisheries and Food (1973).

$\mathrm{Mg}$ concentrations were measured by atomic absorption spectrophotometry (Pye Unicam SP191) using lanthanum chloride $(0 \cdot 1 \mathrm{~g} / \mathrm{l})$ as diluent, $\mathrm{Na}$ and $\mathrm{K}$ by emission spectrophotometry (Pye Unicam SP90), Ca and phosphate by AutoAnalyzer techniques (Technicon, 1967, 1969) and $\mathrm{NH}_{3}$ by the method of Fawcett \& Scott (1960) adapted for use on an AutoAnalyzer (Aubrey Jones, 1982). Cl was determined using a chloride ion electrode (model no. 8004-2; EIL) in conjunction with an Ionalyzer digital pH meter (model no. 801; Orion Research). The osmotic pressure of rumen fluid was determined with an Osmette Precision Osmometer (Precision Systems Inc., Newton, Mass., USA).

Blood packed-cell volume was measured using haematocrit capillary tubes in conjunction with an MSE centrifuge with a haematocrit head attachment.

The concentrations of PEG in rumen fluid were determined turbidimetrically by a modified method of Malawar \& Powell (1967) using a Pye Unicam UV600 at wavelength $650 \mu \mathrm{m}$.

In preparation for mineral analysis the centrifuged samples of rumen fluid were thawed at room temperature, and then centrifuged in stoppered tubes at $30000 \mathrm{~g}$ for $30 \mathrm{~min}$ (ultracentrifuged). The supernatant fraction was used for analysis.

PD across the rumen wall was measured by the method of Dobson \& Phillipson (1958), modified for use with rumen cannulas by Brown (1980).

$\mathrm{pH}$ was measured in rumen fluid and urine using an EIL $\mathrm{pH}$ meter incorporating temperature correction.

\section{Statistical analyses}

Plots of the values from the blood and rumen samples showed similar time trends throughout the day over sheep within diets. Therefore average values were calculated for each sampling time, within each sheep, over days, on each diet.

This approach was used because of the different periods over which each variable was studied. For example, blood samples were taken on days $1,2,3,4,11$ and 12 , but the latter $2 \mathrm{~d}$ were considered separately from the first $4 \mathrm{~d}$.

The data were then analysed by regression or by analysis of variance.

Rumen values were also tested by compartmental models.

\section{RESULTS}

Each sheep ate virtually all the food when fed on the dry diets, but three sheep refused some of the frozen grass (diet FG). However, the amount refused was always less than $2.5 \%$ of the total amount fed. The mineral content of the four diets is given in Table 1.

The mean daily intakes of $\mathrm{Mg}, \mathrm{Ca}$ and phosphate, their apparent availabilities, urinary excretions and $\mathrm{pH}$ are given in Table 2.

Both the apparent availability $(P<0.05)$ and urinary excretion $(P<0.01)$ of $\mathrm{Mg}$ were significantly lower on the grass diets compared with diet $\mathrm{BH}$. There was also a significantly higher $(P<0.01)$ percentage urinary excretion of $\mathrm{Mg}$ on diet $\mathrm{MH}$ than on the other three diets. There were no significant differences in the urine $\mathrm{pH}$ values. 
Table 1. Mineral composition of the diets ( $g$ dry matter $/ \mathrm{kg}$ ) given to sheep

\begin{tabular}{llllll}
\hline \hline Diet... & BH & MH & DG & FG \\
Dry matter $(\mathrm{g} / \mathrm{kg}) \ldots$ & 821 & 827 & 844 & 148 \\
\hline Magnesium & & 2.5 & 1.9 & 1.5 & 2.4 \\
Calcium & & 3.8 & 3.5 & 6.5 & 4.8 \\
Phosphate & 3.8 & 2.2 & 3.3 & 4.3 \\
Sodium & 1.2 & 1.0 & 2.8 & 1.7 \\
& Potassium & 8.5 & 8.5 & 20.4 & 33.8 \\
\hline
\end{tabular}

$\mathrm{BH}, 600 \mathrm{~g}$ rolled barley $+400 \mathrm{~g}$ chopped hay $/ \mathrm{kg} ; \mathrm{MH}, 600 \mathrm{~g}$ flaked maize $+400 \mathrm{~g}$ chopped hay $/ \mathrm{kg} ; \mathrm{DG}, \mathrm{dried}-$ grass cobs; FG, frozen grass.

Table 2. Effect of change of diet on mean daily intakes (mmol/d), apparent availability (\%) and urinary excretion (\%) of magnesium, calcium and phosphate, and urine $p H$ and the retention of $\mathrm{Mg}(\mathrm{mmol} / \mathrm{d})$ in sheep

\begin{tabular}{|c|c|c|c|c|c|c|}
\hline Diet... & BH & MH & DG & FG & SED & $\begin{array}{l}\text { Statistical } \\
\text { significance } \\
\qquad(F)\end{array}$ \\
\hline \multicolumn{7}{|l|}{ Intake (mmol/d) } \\
\hline $\mathrm{Mg}$ & $84 \cdot 1$ & $61 \cdot 0$ & $47 \cdot 9$ & 85.8 & $3 \cdot 70$ & $* * *$ \\
\hline $\mathrm{Ca}$ & $76 \cdot 3$ & $68 \cdot 4$ & $133 \cdot 8$ & $102 \cdot 5$ & $14 \cdot 78$ & $* * *$ \\
\hline Phosphate & $101 \cdot 9$ & $57 \cdot 3$ & $84 \cdot 6$ & $118 \cdot 9$ & $9 \cdot 58$ & $* * *$ \\
\hline \multicolumn{7}{|l|}{ Apparent availability (\%) } \\
\hline $\mathrm{Mg}$ & $47 \cdot 3$ & 37.6 & $27 \cdot 6$ & 34.9 & $2 \cdot 83$ & $*$ \\
\hline $\mathrm{Ca}$ & $-4 \cdot 1$ & $-4 \cdot 5$ & 5.8 & $0 \cdot 1$ & 2.74 & NS \\
\hline Phosphate & $12 \cdot 5$ & $-31 \cdot 8$ & $12 \cdot 0$ & $25 \cdot 3$ & $3 \cdot 44$ & $* * *$ \\
\hline \multicolumn{7}{|l|}{ Urinary excretion (\%) } \\
\hline $\mathrm{Mg}$ & $36 \cdot 3$ & $46 \cdot 3$ & $26 \cdot 3$ & $24 \cdot 9$ & $1 \cdot 37$ & $* * *$ \\
\hline $\mathrm{Ca}$ & $9 \cdot 6$ & $15 \cdot 5$ & $0 \cdot 3$ & $0 \cdot 9$ & $1 \cdot 43$ & $* * *$ \\
\hline Phosphate & $2 \cdot 6$ & $1 \cdot 4$ & $3 \cdot 3$ & $6 \cdot 4$ & 1.95 & NS \\
\hline Retention (mmol $\mathrm{Mg} / \mathrm{d}$ ) & $9 \cdot 4$ & $-5 \cdot 3$ & $0 \cdot 5$ & 8.9 & 1.92 & $* *$ \\
\hline Urine $\mathrm{pH}$ & $8 \cdot 48$ & $8 \cdot 50$ & 8.93 & $8 \cdot 90$ & $0 \cdot 113$ & NS \\
\hline $\begin{array}{l}\text { Apparent availability } \\
(\mathrm{mmol} \mathrm{Mg} / \mathrm{d})\end{array}$ & $40 \cdot 2$ & $23 \cdot 0$ & $13 \cdot 1$ & $30 \cdot 2$ & 3.99 & $* * *$ \\
\hline Urine $\mathrm{Mg}(\mathrm{mmol} / \mathrm{d})$ & $30 \cdot 8$ & $28 \cdot 30$ & $12 \cdot 6$ & $21 \cdot 4$ & $1 \cdot 85$ & $* * *$ \\
\hline $\begin{array}{l}\text { Urine } \mathrm{Mg} \text {; apparent } \mathrm{Mg} \\
\text { availability }\end{array}$ & 0.776 & 1.232 & 0.952 & 0.712 & 0.090 & $* *$ \\
\hline Error df 6 & & & & & & \\
\hline
\end{tabular}

$\mathrm{BH}, 600 \mathrm{~g}$ rolled barley $+400 \mathrm{~g}$ chopped hay $/ \mathrm{kg} ; \mathrm{MH}, 600 \mathrm{~g}$ flaked maize $+400 \mathrm{~g}$ chopped hay $/ \mathrm{kg}$; DG, driedgrass cobs; FG, frozen grass; SED, standard error of difference; NS, not significant.

${ }^{*} P<0.05,{ }^{* *} P<0.01,{ }^{* *} P<0.001$.

The plasma concentrations of $\mathrm{Mg}, \mathrm{Ca}$ and phosphate in the samples taken on the first $4 \mathrm{~d}$ after a change in diet ranged from 0.85 to 0.97 , from 2.46 to 2.65 and from 1.12 to 1.78 $\mathrm{mmol} / 1$ respectively. There were no significant differences between diets or within days for any of these variables.

Table 3 gives the mean plasma concentration of $\mathrm{Mg}$ at intervals through the last $2 \mathrm{~d}$ of a treatment period. The highest recorded values all occurred about $6 \mathrm{~h}$ after feeding $(15.00$ 
Table 3. Effect of change of diet on mean concentrations of magnesium, calcium and phosphate ( $\mathrm{mmol} / \mathrm{l})$ in plasma, and packed cell volume, during the last $2 d$ of a balance period in sheep ${ }_{\dagger}^{\dagger}$

\begin{tabular}{|c|c|c|c|c|c|c|}
\hline $\begin{array}{l}\text { Diet ... } \\
\text { Time of day (hours) }\end{array}$ & BH & $\mathrm{MH}$ & DG & $\mathrm{FG}$ & SED & $\begin{array}{c}\text { Statistical } \\
\text { significance } \\
F\end{array}$ \\
\hline \multicolumn{7}{|c|}{$\mathrm{Mg}$} \\
\hline 08.45 & 0.95 & 0.96 & 0.83 & 0.91 & 0.019 & ** \\
\hline 11.00 & 0.97 & 1.00 & 0.85 & 0.91 & 0.019 & $* * *$ \\
\hline 15.00 & 1.00 & 1.03 & 0.87 & 0.94 & 0.030 & ** \\
\hline 20.45 & 0.95 & 0.96 & 0.81 & 0.91 & 0.010 & $* * *$ \\
\hline \multicolumn{7}{|c|}{$\mathrm{Ca}$} \\
\hline 08.45 & $2 \cdot 51$ & $2 \cdot 57$ & 2.56 & $2 \cdot 58$ & 0.041 & $*$ \\
\hline 11.00 & $2 \cdot 50$ & $2 \cdot 47$ & 2.56 & $2 \cdot 42$ & $0 \cdot 102$ & $* *$ \\
\hline 15.00 & $2 \cdot 54$ & $2 \cdot 54$ & $2 \cdot 46$ & $2 \cdot 60$ & 0.060 & ** \\
\hline 20.45 & $2 \cdot 50$ & $2 \cdot 46$ & 2.49 & $2 \cdot 58$ & 0.059 & $*$ \\
\hline \multicolumn{7}{|c|}{ Phosphate } \\
\hline 08.45 & 1.67 & 1.56 & 1.46 & $2 \cdot 11$ & $0 \cdot 154$ & $* *$ \\
\hline 11.00 & 1.59 & $1 \cdot 33$ & $1 \cdot 37$ & $2 \cdot 14$ & 0.201 & $* * *$ \\
\hline 15.00 & 1.55 & 1.43 & 1.51 & 1.99 & 0.198 & $* * *$ \\
\hline 20.45 & $1 \cdot 52$ & $1 \cdot 44$ & 1.45 & 1.99 & $0 \cdot 200$ & $* *$ \\
\hline \multicolumn{7}{|c|}{ Packed cell volume } \\
\hline 08.45 & $29 \cdot 5$ & $28 \cdot 9$ & $30 \cdot 0$ & $29 \cdot 3$ & $0-70$ & $*$ \\
\hline 11.00 & $29 \cdot 9$ & $28 \cdot 9$ & $29 \cdot 6$ & $29 \cdot 2$ & $1 \cdot 32$ & * \\
\hline 15.00 & $28 \cdot 5$ & $28 \cdot 5$ & $29 \cdot 0$ & $28 \cdot 6$ & 0.49 & $*$ \\
\hline 20.45 & $27 \cdot 8$ & 26.8 & $29 \cdot 1$ & $30-1$ & $1 \cdot 37$ & $*$ \\
\hline Error df 6 & & & & & & \\
\hline
\end{tabular}

$\mathrm{BH}, 600 \mathrm{~g}$ rolled barley $+400 \mathrm{~g}$ chopped hay $/ \mathrm{kg} ; \mathrm{MH}, 600 \mathrm{~g}$ flaked maize $+400 \mathrm{~g}$ chopped hay $/ \mathrm{kg}$; DG, driedgrass cobs; FG, frozen grass; SED, standard error of difference; NS, not significant.

${ }^{*} P<0.05,{ }^{* *} P<0.01,{ }^{* * *} P<0.001$.

$\uparrow$ For details of procedures, see p. 584 .

hours). By 20.45 hours minimum observed values were also seen on all diets, but thereafter the pattern of change varied with the diet. Thus at 08.45 hours the concentrations for diets $\mathrm{BH}, \mathrm{MH}$ and FG remained at the minimum, whereas diet DG showed a rise. At 11.00 hours diets $\mathrm{BH}$ and $\mathrm{MH}$ showed increases, diet DG increased further, but diet FG remained at the level observed at 20.45 hours.

When grass diets were given, the $\mathrm{Mg}$ concentration was significantly lower than that for diets $\mathrm{BH}$ and $\mathrm{MH}$ at 11.00 and 20.45 hours $(P<0.05)$ and on diet DG the concentration was significantly lower $(P<0.05)$ than on diet FG. The concentration of plasma Ca was not significantly different at any point, but the concentration of phosphate was significantly higher $(P<0.05)$ at 08.45 and 11.00 hours when diet FG was given. The mean values for blood packed cell volume were not significantly different on any diet.

The concentrations of $\mathrm{Mg}, \mathrm{Ca}, \mathrm{K}, \mathrm{NH}_{3}, \mathrm{Cl}, \mathrm{Na}$ and phosphate in ultracentrifuged rumen fluid at intervals throughout the day are given in Figs. 1 and 2. The concentrations of $\mathrm{Mg}$, $\mathrm{Ca}, \mathrm{K}$ and $\mathrm{Cl}$ increased after feeding ( 08.45 hours), whereas the concentrations of phosphate and $\mathrm{Na}$ tended to fall on all the diets.

The concentration of $\mathrm{NH}_{3}$ in rumen fluid (Fig. 1) was significantly higher $(P<0.01)$ throughout the day on diet FG than on the other three diets, except for diet DG at 08.45 hours. Differences also occurred between diets in the pattern of $\mathrm{NH}_{3}$ concentration after feeding. When diet $\mathrm{FG}$ was given the concentration of $\mathrm{NH}_{3}$ was lowest immediately before feeding, but on the other diets it was lowest $6 \mathrm{~h}$ after feeding. 

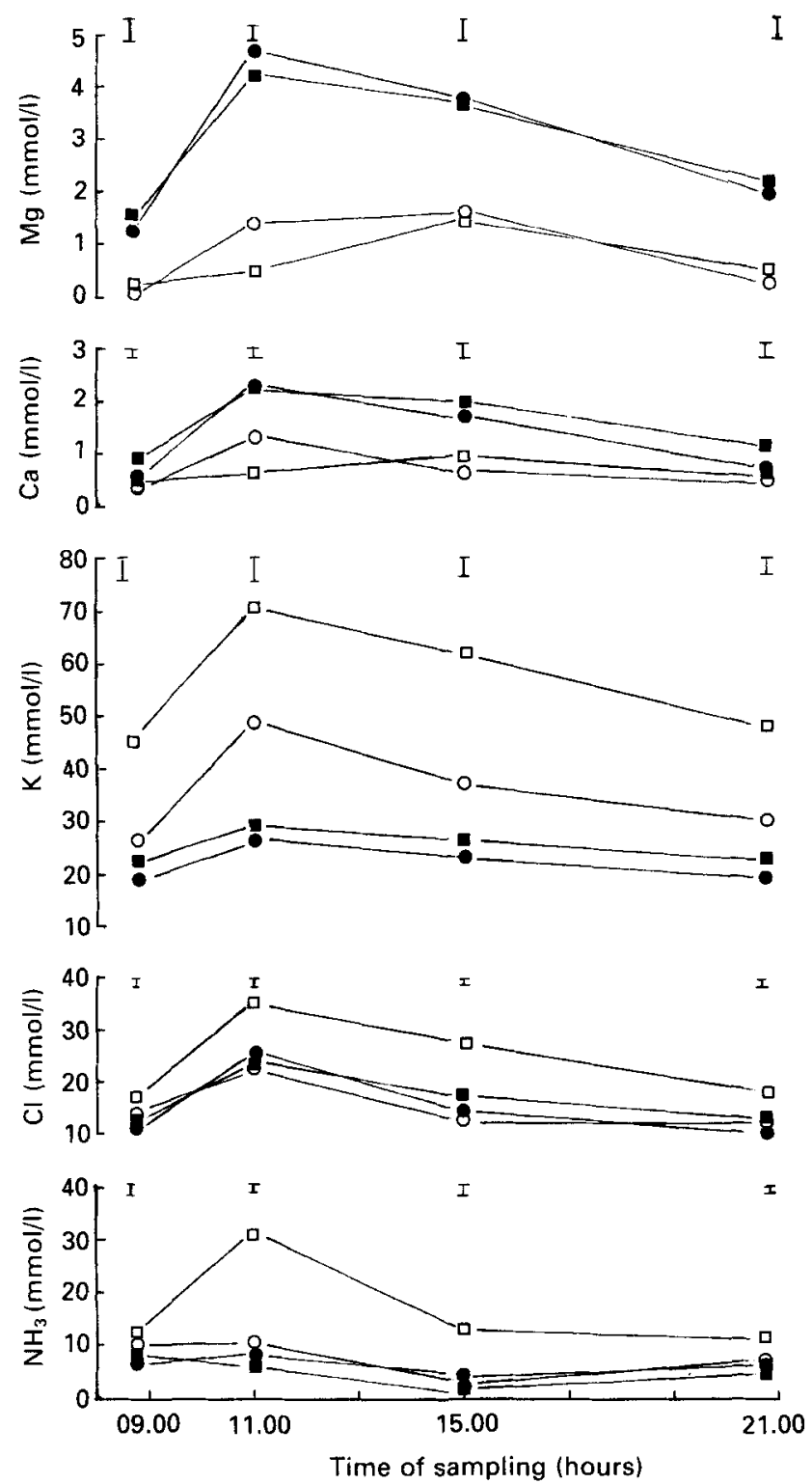

Fig. 1. Effect of change of diet on mean concentrations (mmol/1) of magnesium, calcium, potassium, chloride and ammonia in rumen fluid at intervals through the day. $(\mathrm{O}-\mathrm{O})$, Diet $\mathrm{BH}, 600 \mathrm{~g}$ rolled barley $+400 \mathrm{~g}$ chopped hay $/ \mathrm{kg}$; (- ) , diet $\mathrm{MH}, 600 \mathrm{~g}$ flaked maize $+400 \mathrm{~g}$ chopped hay $/ \mathrm{kg}$; $(\square-\square$ ), diet $F G$, frozen grass; ( $\square-\square$ ), diet DG, dried-grass cobs (for details of feeding regimen, see p. 584). Values are means with their standard errors represented by vertical bars.

In spite of the large changes that occurred in the mineral composition of rumen fluid on diets $D G$ and $F G$, osmolality was not significantly different. However, the $\mathrm{pH}$ of rumen fluid was significantly higher $(P<0.01)$ on both diets DG and FG throughout the day, as was the PD $(P<0.01)$ between rumen contents and blood (blood positive) (Table 4).

Fig. 3 shows that the quantity of water imbibed during the balance periods was significantly lower $(P<0.01)$ when diet $\mathrm{FG}$ was given, and the effect was evident from the 

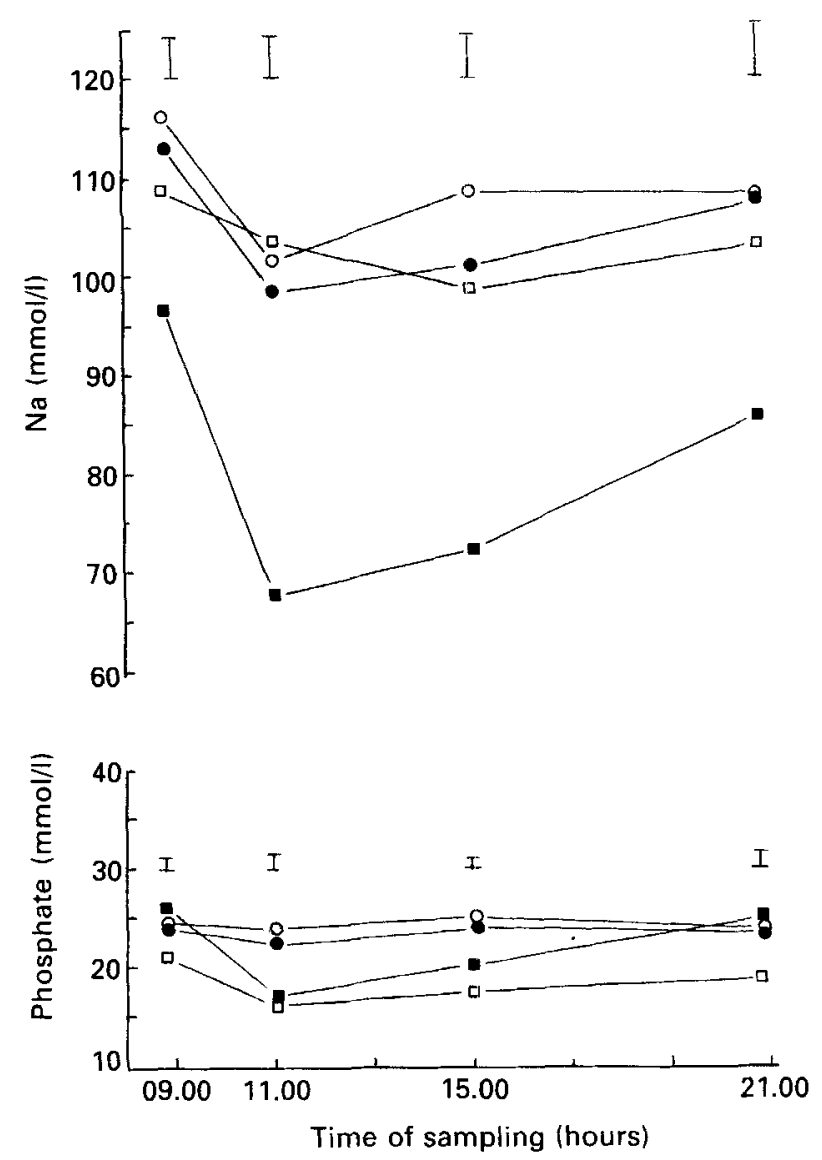

Fig. 2. Effect of change of diet on mean concentrations $(\mathrm{mmol} / 1)$ of sodium and phosphate in rumen fluid at intervals through the day. $(\mathrm{O}-\mathrm{O})$, Diet $\mathrm{BH}, 600 \mathrm{~g}$ rolled barley $+400 \mathrm{~g}$ chopped hay $/ \mathrm{kg}$; (- - ) , diet $\mathrm{MH}, 600 \mathrm{~g}$ flaked maize $+400 \mathrm{~g}$ chopped hay $/ \mathrm{kg} ;(\square-\square)$, diet $\mathrm{FG}$, frozen grass; (1- D), diet DG, dried-grass cobs (for details of feeding regimen see p. 584). Values are means with their standard errors represented by vertical bars.

second $12 \mathrm{~h}$ period after a change in diet. However, the total water intake (imbided plus dietary) was significantly higher $(P<0.001)$ on diet $\mathrm{FG}$ than on any of the other diets.

The rumen-fluid volume, measured $6 \mathrm{~h}$ after feeding, was significantly greater $(P<0 \cdot 05)$ on diet DG than on diets FG or $\mathrm{MH}$, and the rumen fluid dilution rate (Warner \& Stacy, 1968) was significantly higher $(P<0.05)$ on diet MH (Table 5).

\section{DISCUSSTON}

The type of diet (forage, grass, concentrates, etc.) and its mineral content, the pattern of feeding and rumination, and the salivary volume, composition and flow-rate will all influence the release of substances from the diet. In the present experiment the patterns of concentration of $\mathrm{Mg}, \mathrm{Ca}, \mathrm{K}, \mathrm{Cl}$ and $\mathrm{NH}_{3}$ in rumen fluid, with respect to time, belong to the same family of curves. These can be described by the following equation, derived from the concept of the rumen as a two-compartment model (Czerkawski, 1986):

$$
C=A \exp \left(-D_{1} t\right)+B \exp \left(-D_{2} t\right)
$$


Table 4. Effect of change of diet on mean osmotic pressure ( $\mathrm{mOsmol} / \mathrm{l})$ and $\mathrm{pH}$ of rumen fuid, and the potential difference $(\mathrm{mV})$ between rumen contents and blood at intervals throughout the day in sheep

\begin{tabular}{|c|c|c|c|c|c|c|}
\hline $\begin{array}{l}\text { Diet ... } \\
\text { Time of day (hours) }\end{array}$ & $\mathrm{BH}$ & $\mathrm{MH}$ & DG & $\mathrm{FG}$ & SED & $\begin{array}{c}\text { Statistical } \\
\text { significance } \\
F\end{array}$ \\
\hline \multicolumn{7}{|c|}{ Osmotic pressure (mOsmol/l) } \\
\hline 08.45 & 229 & 243 & 224 & 239 & $8 \cdot 5$ & NS \\
\hline 11.00 & 263 & 255 & 287 & 285 & $12 \cdot 6$ & NS \\
\hline 15.00 & 256 & 252 & 240 & 253 & $12 \cdot 2$ & NS \\
\hline 20.45 & 244 & 245 & 225 & 232 & $15 \cdot 2$ & NS \\
\hline & & & $\mathrm{pH}$ & & & \\
\hline 08.45 & $6 \cdot 58$ & 6.43 & 7.24 & $7 \cdot 09$ & $0 \cdot 12$ & $* *$ \\
\hline 11.00 & 5.99 & 5.89 & $6 \cdot 42$ & 6.63 & 0.07 & $* * *$ \\
\hline 15.00 & 6.02 & $5 \cdot 89$ & 6.39 & 6.45 & 0.07 & $* * *$ \\
\hline 20.45 & 6.34 & $6 \cdot 14$ & 6.88 & 6.89 & $0 \cdot 10$ & $* * *$ \\
\hline $\begin{array}{l}\text { Potential } \\
\text { difference }(\mathrm{mV})\end{array}$ & $29 \cdot 3$ & $27 \cdot 4$ & $37 \cdot 4$ & $39 \cdot 7$ & $1 \cdot 38$ & $* * *$ \\
\hline Error df 6 & & & & & & \\
\hline
\end{tabular}

$\mathrm{BH}, 600 \mathrm{~g}$ rolled barley $+400 \mathrm{~g}$ chopped hay $/ \mathrm{kg} ; \mathrm{MH}, 600 \mathrm{~g}$ flaked maize $+400 \mathrm{~g}$ chopped hay $/ \mathrm{kg} ; \mathrm{DG}$, driedgrass cobs; FG, frozen grass; SED, standard error of difference; NS, not significant.

${ }^{* *} P<0.01,{ }^{* * *} P<0.001$.
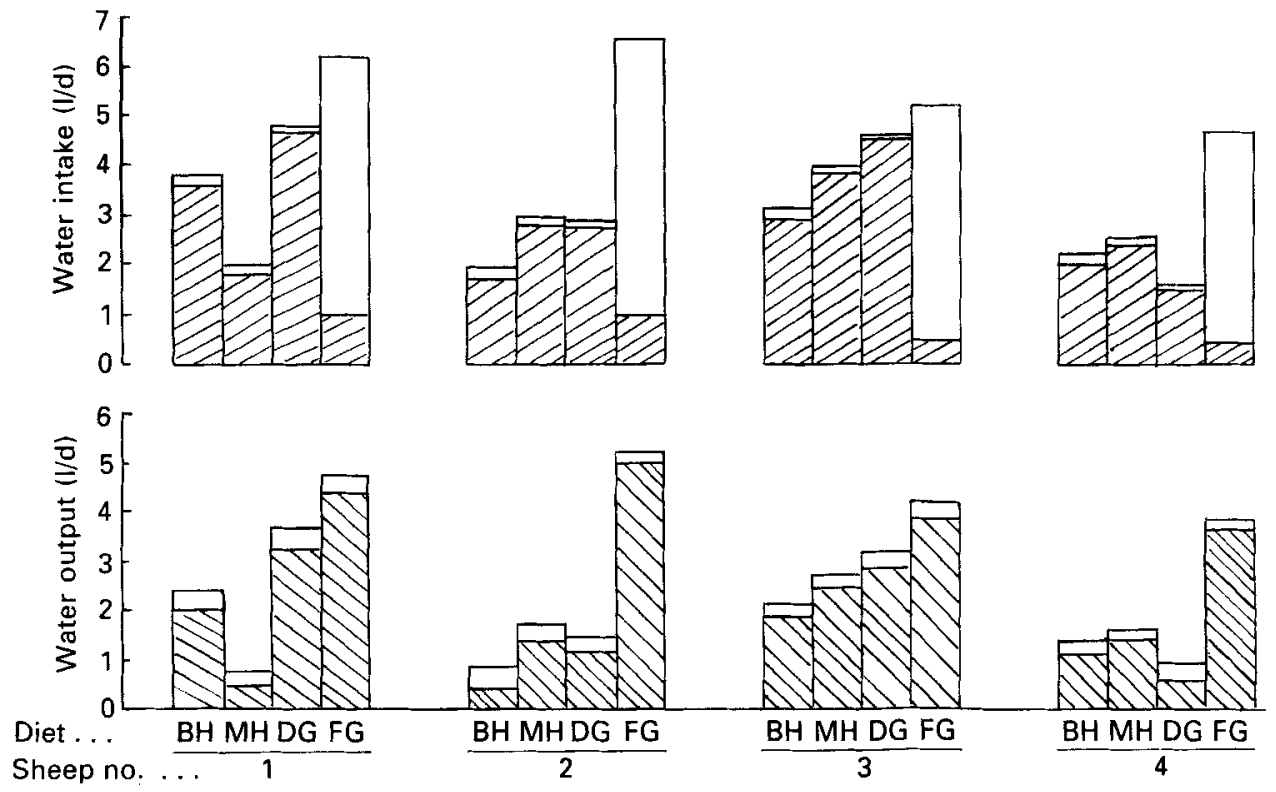

Fig. 3. Effects of change of diet on mean total intakes and outputs of water (l/d) by four sheep. 勿, Imbibed water; $\square$, food water; $\mathbb{N}$, urine; $\square$, faecal water. Diet $\mathrm{BH}, 600 \mathrm{~g}$ rolled barley $+400 \mathrm{~g}$ chopped hay $/ \mathrm{kg}$; diet $\mathrm{MH}, 600 \mathrm{~g}$ flaked maize $+400 \mathrm{~g}$ chopped hay; diet DG, dried-grass cobs; diet FG, frozen grass (for details of feeding regimen see p. 584). 
Table 5. Effect of change of diet on daily mean rumen liquid volume $(l)$ and dilution rate $(l / h)$ of sheep over each 12 d balance period

\begin{tabular}{lcccccc}
\hline \hline & & & & & \multicolumn{3}{c}{$\begin{array}{c}\text { Statistical } \\
\text { significance } \\
\text { Diet } \ldots\end{array}$} & BH & MH & DG & FG & SED & F \\
\hline Rumen liquid volume (l) & 5.36 & 4.68 & 6.02 & 5.09 & 0.319 & $*$ \\
Dilution rate (l/h) & 0.070 & 0.091 & 0.056 & 0.062 & 0.0082 & $*$ \\
\hline \hline
\end{tabular}

$\mathrm{BH}, 600 \mathrm{~g}$ rolled barley $+400 \mathrm{~g}$ chopped hay $/ \mathrm{kg} ; \mathrm{MH}, 600 \mathrm{~g}$ flaked maize $+400 \mathrm{~g}$ chopped hay $/ \mathrm{kg} ; \mathrm{DG}$, driedgrass cobs; FG, frozen grass; SED, standard error of difference.

$* P<0.05$.

where $C$ is the concentration, $A, B, D_{1}$ and $D_{2}$ are parameters, and $t$ is time. The estimates of the parameters of the equation can be calculated by the 'curve-peeling' technique, and the value of the maximum concentration $\left(t_{\max }\right)$ is then calculated from them. For example, using values in Fig. 1 for diet $\mathrm{BH}, \mathrm{Mg}$ is estimated at $t_{\max }=11.30$ hours as $4.8 \mathrm{mmol} / 1$, very close to the observed value of $4.7 \mathrm{mmol} / 1$ at 11.00 hours. Unlike $\mathrm{Ca}, \mathrm{K}, \mathrm{Cl}$ and $\mathrm{NH}_{3}$, the time at which $t_{\max }$ of $\mathrm{Mg}$ occurred varied with the diet. For diets $\mathrm{BH}$ and $\mathrm{MH}$ it coincided with $t_{\max }$ for the other substances, but for diets DG and FG it occurred $4 \mathrm{~h}$ later. Although in the case of diet FG this may partly reflect a slower rate of eating, this could not be so in the case of diet DG since this was always eaten within $0.5 \mathrm{~h}$ of feeding; similarly with diets $\mathrm{BH}$ and $\mathrm{MH}$.

With so few sampling times per $24 \mathrm{~h}$ it is not possible to determine precisely the time of maximum concentrations which could differ significantly from the estimated values. Also the recorded maximum concentrations are not necessarily the same as the maximum concentrations. However, it can be deduced from Fig. 1 that the maximum concentrations of $\mathrm{Mg}$ for diets $\mathrm{BH}$ and $\mathrm{MH}$ would have occurred between the second and third sampling times, whereas for diets DG and FG they would be most likely to have been between the third and fourth sampling times.

A possible explanation for the differences in the apparent rates of release of $\mathrm{Mg}$ is the difference in the rates of fermentation of cereal grains and forages in the rumen. Also, there could be an effect of the form in which $\mathrm{Mg}$ is held in plant tissues. In cereal grains minerals are held almost entirely in the aleurone layer, and $\mathrm{Mg}$ is present as the salt of inositol hexaphosphoric acid. In vegetative tissues about $70 \%$ of $\mathrm{Mg}$ is diffusible and associated with inorganic anions and organic ions such as malate and citrate. It is also associated with indiffusible anions including oxalate and pectate (Mengel \& Kirkby, 1982).

The patterns for $\mathrm{Na}$ and phosphate belong to a different family of curves, and with the values from the present experiment cannot adequately be described by the twocompartment model.

Both the concentration of $\mathrm{K}$ and the $\mathrm{Na}: \mathrm{K}$ ratio have been shown to affect the absorption of $\mathrm{Mg}$ from the reticulo-rumen (Tomas \& Potter, 1976; Wylie et al. 1985). In the present experiment the $\mathrm{K}$ concentration in rumen fluid was highest and the $\mathrm{Na}$ concentration lowest about $2 \mathrm{~h}$ after feeding (Figs. 1 and 2). In addition, on diet FG the concentration of $\mathrm{Mg}$ was almost at its lowest recorded level at this time. In contrast, the dry diets produced their peak concentrations of $\mathrm{Mg} 2 \mathrm{~h}$ after feeding.

It has also been shown that $\mathrm{NH}_{3}$ reduces $\mathrm{Mg}$ absorption, and is additive to the effect of the $\mathrm{Na}: \mathrm{K}$ ratio (Care et al. 1984). The concentration of $\mathrm{NH}_{3}$ in rumen fluid was always significantly higher $(P<0.01)$ on diet $\mathrm{FG}$ than on other diets, except diet DG at 08.45 
Table 6. Effect of change of diet on mean $\mathrm{Na}: \mathrm{K}$ ratio in rumen fluid at intervals throughout the day in sheep

\begin{tabular}{|c|c|c|c|c|c|c|}
\hline $\begin{array}{l}\text { Diet ... } \\
\text { Time of day (hours) }\end{array}$ & BH & $\mathrm{MH}$ & DG & FG & SED & $\begin{array}{c}\text { Statistical } \\
\text { significance } \\
F\end{array}$ \\
\hline 08.45 & $6 \cdot 6$ & $5 \cdot 4$ & $4 \cdot 2$ & $2 \cdot 4$ & 0.65 & $* *$ \\
\hline 11.00 & 3.9 & 3.4 & $2 \cdot 1$ & $1 \cdot 0$ & 0.31 & $* * *$ \\
\hline 15.00 & $5 \cdot 2$ & $3 \cdot 9$ & $2 \cdot 7$ & $1 \cdot 2$ & 0.49 & $* *$ \\
\hline 20.45 & $5 \cdot 7$ & $4 \cdot 9$ & 3.5 & 1.9 & $0 \cdot 37$ & $* * *$ \\
\hline
\end{tabular}

$\mathrm{BH}, 600 \mathrm{~g}$ rolled barley $+400 \mathrm{~g}$ chopped hay $/ \mathrm{kg} ; \mathrm{MH}, 600 \mathrm{~g}$ flaked maize $+400 \mathrm{~g}$ chopped hay $/ \mathrm{kg} ; \mathrm{DG}$, driedgrass cobs; FG, frozen grass; SED, standard error of difference.

** $P<0.01, * * * P<0.001$.

hours. On diet FG the peak concentration occurred about $2 \mathrm{~h}$ after feeding, reaching a level of $31 \mathrm{mmol} / 1$. This is within the range reported by Annison et al. (1959) when they changed sheep from dry diets to fresh spring grass.

Studies have indicated that the PD between blood and rumen contents might also affect $\mathrm{Mg}$ absorption (Tomas \& Potter, 1976; Brown, 1980). In the present experiment the PD was significantly greater $(P<0.001)$ on diets FG and DG than on the other two diets which were similar to each other.

The pattern of $\mathrm{pH}$ with time was similar on all diets, but $\mathrm{pH}$ values were significantly higher $(P<0.01)$ on both grass diets throughout the day. Similarly high values have been observed in animals fed on fresh grass (Bryant, 1964; Horn \& Smith, 1978), but others have reported lower values when animals ate grass than when they ate dry diets (Phillipson, 1952; Balch \& Rowland, 1957; Johnson et al. 1988). This apparent anomaly may be a reflection of the amount of grass eaten. In the present experiment the sheep were fed at about maintenance level, whereas the cows were allowed to eat grass ad lib. (Johnson et al. 1988). This might also explain the narrow range of values recorded for the osmolality of rumen fluid. In the cows the range was much wider throughout the day, with average values of 223-404 mOsmol $/ \mathrm{kg}$.

Very close inverse relations were observed between the $\mathrm{pH}$ of rumen fluid and the concentrations of ultracentrifuged $\mathrm{Mg}$ and $\mathrm{Ca}(r-0.95, P<0.001$ and $r-0.89, P<0.001$ respectively). These relations are similar to those observed in the dairy cows, and are best described by logistic curves of the form

$$
y=a+c /\left(1+e^{-b(x-m)}\right),
$$

where $y$ is concentration of $\mathrm{Mg}$ and $\mathrm{Ca}$ in ultracentrifuged rumen fluid (mmol/l), $x$ is $\mathrm{pH}$ and $a, b, c$ and $m$ are parameters estimated by non-linear least squares using the Maximum Likelihood Program (Lawes Agricultural Trust, 1980). This suggests that the binding of $\mathrm{Mg}$ in rumen contents was altered by $\mathrm{pH}$, and this view is supported by the in vitro findings of Smith \& Horn (1976) and Nikolic et al. (1977).

The mean concentration of $\mathrm{Mg}$ in ultracentrifuged rumen fluid was significantly lower $(P$ $<0.01)$ at $11.00,15.00$ and 20.45 hours when the grass diets were given, and this is related to the higher $\mathrm{pH}$ values. The fitted curves show that, for all diets, when the $\mathrm{pH}$ of rumen fluid rose above 6.5 the concentration of $\mathrm{Mg}$ fell rapidly. On diet $\mathrm{FG}$ the $\mathrm{pH}$ was only below 6.5 about $6 \mathrm{~h}$ after feeding.

Multiple regression analysis showed that the apparent availability of $\mathrm{Mg}(y)$ was more 
closely associated $(R-0.67)$ with $\mathrm{pH}(x)$ (Table 4$)$ and $\mathrm{Na}: \mathrm{K}$ ratio $(w)$ (Table 6$)$ of rumen fluid where

$$
y=112 \cdot 8+1.81(\text { SE } 1.509) w-12.68(\text { SE 7.479) } x .
$$

Thus on diet FG the greatest antagonistic effects of the concentrations of $\mathrm{NH}_{3}$ and $\mathrm{K}$, the $\mathrm{Na}: \mathrm{K}$ ratio, the PD between blood and rumen contents and rumen $\mathrm{pH}$ all occurred when the concentration of dissolved $\mathrm{Mg}$ was about at its lowest.

There was a significantly higher $(P<0.05)$ proportionate output of the apparently available $\mathrm{Mg}$ in urine on diet $\mathrm{MH}$ than on diet $\mathrm{BH}(P<0.01)$ or diet FG $(P<0.05)$ (Table 2). This has also been reported in cattle (Rook \& Campling, 1962). Diet DG supplied only $57 \%$ of the apparently available $\mathrm{Mg}$ compared with diet $\mathrm{MH}$, yet the sheep were in zero $\mathrm{Mg}$ balance on diet DG.

Whilst the $\mathrm{pH}$ of the urine (Table 2) would cause the formation of insoluble $\mathrm{Mg}$ it would affect all diets similarly. It is, therefore, possible that some substance, directly or indirectly related to flaked maize, inhibited the resorption of $\mathrm{Mg}$ in the kidney.

The sheep drank significantly less water $(P<0.01)$ when they were fed on diet FG and they reduced their imbibed water within $1 \mathrm{~d}$ of the dietary change. Nevertheless, their total water intake (imbibed plus dietary water) was twice as high as when they were fed on diet $\mathrm{BH}$. The volume $(V)$ of liquid in the rumen (measured via PEG) was greatest when diet DG was given, and was significantly different from diets MH and FG $(P<0.05)$. There was a tendency for a lower dilution rate $(1 / \mathrm{h})(D)$ on diet $\mathrm{DG}$, but only diet $\mathrm{MH}$ had a significantly higher rate $(P<0.05)$ (Table 5$)$. However, the fractional outflow rates, $F=$ $V \times D$, were lower for the grass-based diets than for the other two diets (FG 0.314, DG $0 \cdot 337$, BH $0 \cdot 374$, MH 0.424).

\section{REFERENCES}

Annison, E. F., Lewis, D. \& Lindsay, D. B. (1959). The metabolic changes which occur in sheep transferred to lush spring grass. 1. Changes in blood and rumen constituents. Journal of Agricultural Science, Cambridge 53, 3441 .

Aubrey Jones, D. A. (1982). Studies on the effects of conserved and fresh diets on water balance, rumen function and magnesium metabolism in dairy cows and sheep. PhD Thesis, University of Leeds.

Balch, D. A. \& Rowland, S. J. (1957). Volatile fatty acids and lactic acid in the rumen of cows receiving a variety of diets. British Journal of Nutrition 11, 288-298.

Brown, R. C. (1980). Studies on the absorption of magnesium from the rumen of sheep. PhD Thesis, University of Leeds.

Bryant, A. M. (1964). Variations in the $\mathrm{pH}$ and volatile fatty acid concentration within the rumen. New Zealand Journal of Agricultural Research 7, 694-706.

Care, A. D., Brown, R. C. \& Pickard, D. W. (1984). Magnesium absorption from the digestive tract of sheep. Quarterly Journal of Experimental Physiology 69, 577-587.

Care, A. D., Vowles, L. E., Mann, S. O. \& Ross, D. B. (1967). Factors affecting magnesium absorption in relation to the aetiology of acute hypomagnesaemia. Journal of Agricultural Science, Cambridge 68, 195-204.

Czerkawski, J. W. (1986). An Introduction to Rumen Studies. Oxford: Pergamon Press.

Dobson, A. \& Phillipson, A. T. (1958). The absorption of chloride ions from the reticulo rumen sac. Journal of Physiology 140, 94-104.

Fawcett, J. K. \& Scott, J. E. (1960). A rapid and precise method for the determination of urea. Journal of Clinical Pathology 13, 156 159.

Horn, J. P. \& Smith, R. H. (1978). Absorption of magnesium by the young steer. British Journal of Nutrition 40 , $473-484$.

Johnson, C. L., Helliwell, S. H. \& Aubrey Jones, D. A. (1988). Magnesium metabolism in the rumens of lactating dairy cows fed on spring grass. Quarterly Journal of Experimental Physiology 73, 23-31.

Lane, G. T., Noiler, C. H., Colenbrander, V. F., Cummings, K. R. \& Harrington, R. B. (1968). Apparatus for obtaining rumenoreticular samples and the effect of sampling location on $\mathrm{pH}$ and volatile fatty acids. Journal of Dairy Science 51, $114-116$.

Lawes Agricultural Trust (1980). Genstat 4.04. Harpenden: Statistics Department, Rothamsted Experimental Station.

Malawer, S. J. \& Powell, D. W. (1967). An improved turbidimetric analysis of polyethylene glycol using an emulsifier. Gastroenterology 53, 250-256. 
Mengel, K. \& Kirkby, E. A. (1982). Principles of Plant Nutrition, 3rd ed., p. 464. Berne: International Potash Institute.

Ministry of Agriculture, Fisheries and Food (1973). The analysis of agricultural materials. Technical Bulletin no. 27. London: H.M. Stationary Office.

Nikolic, J. A., Jovanovic, M. \& Andric, R. (1977). Influence of mineral element concentrations on protein synthesis by rumen micro-organisms in vitro. 1. Magnesium. Acta Veterinaria Yugoslavia 27, 9-19.

Phillipson, A. T. (1952). The fatty acids present in the rumen of lambs fed on a flaked maize ration. British Journal of Nutrition 6, 190-198.

Powley, G. \& Johnson, C. L. (1977). Some effects of conservation of grass upon magnesium metabolism in sheep. Journal of Agricultural Science, Cambridge 88, 477-482.

Rook, J. A. F. \& Campling, R. C. (1962). Magnesium metabolism in the dairy cow. IV. The availability of magnesium in various feedingstuffs. Journal of Agricultural Science, Cambridge 59, 225-232

Smith, R. H. \& Horn, J. P. (1976). Absorption of magnesium labelled with magnesium-28, from the stomach of the young steer. In Nuclear Techniques in Animal Production and Health, pp. 253-260. Vienna: International Atomic Energy Agency.

Technicon (1967). Method N-36; Calcium. Tarrytown, New York: Technicon Instruments Corporation.

Technicon (1969). Method N-46; Inorganic Phosphate. Tarrytown, New York: Technicon Instruments Corporation.

Tomas, F. M. \& Potter, B. J. (1976). The site of magnesium absorption from the ruminant stomach. British Journal of Nutrition 36, 37-45.

Warner, A. C. I. \& Stacy, B. D. (1968). The fate of water in the rumen. 1. A critical appraisal of the use of soluble markers. British Journal of Nutrition 22, 369-387.

Wylie, M. J., Fontenot, J. P. \& Green, L. W. (1985). Absorption of magnesium and other macro-minerals in sheep infused with potassium in different parts of the digestive tract. Journal of Animal Science 61, 1219-1229. 